\title{
Article
}

\section{GIS-Based Multi-Criteria Evaluation for Potential Inland Aquaculture Site Selection in the George Town Conurbation, Malaysia}

\author{
Puteri Nur Atiqah Bandira ${ }^{1}$, Mohd Amirul Mahamud ${ }^{2}{ }^{\infty}$, Narimah Samat ${ }^{2}, * \mathbb{D}$, Mou Leong Tan ${ }^{2}(\mathbb{D}$ \\ and Ngai Weng Chan ${ }^{2}(\mathbb{B}$ \\ 1 School of Industrial Technology, Universiti Sains Malaysia, Gelugor 11800, Penang, Malaysia; \\ puteribandira@student.usm.my \\ 2 GeoInformatics Unit, School of Humanities, Universiti Sains Malaysia, Gelugor 11800, Penang, Malaysia; \\ mohd.amirul@usm.my (M.A.M.); mouleong@usm.my (M.L.T.); nwchan@usm.my (N.W.C.) \\ * Correspondence: narimah@usm.my
}

Citation: Bandira, P.N.A.; Mahamud, M.A.; Samat, N.; Tan, M.L.; Chan, N.W. GIS-Based Multi-Criteria Evaluation for Potential Inland Aquaculture Site Selection in the George Town Conurbation, Malaysia. Land 2021, 10, 1174. https://doi.org/ 10.3390/land 10111174

Academic Editor: Jefferey M. Sellers

Received: 3 September 2021

Accepted: 27 October 2021

Published: 2 November 2021

Publisher's Note: MDPI stays neutral with regard to jurisdictional claims in published maps and institutional affiliations.

Copyright: (c) 2021 by the authors. Licensee MDPI, Basel, Switzerland. This article is an open access article distributed under the terms and conditions of the Creative Commons Attribution (CC BY) license (https:// creativecommons.org/licenses/by/ $4.0 /)$.

\begin{abstract}
Although the aquaculture industry contributes less than $0.2 \%$ to the Gross Domestic Product (GDP) of Malaysia, it has slowly become an important economic activity due to the high-value species productions for domestic and international markets. In addition, aquaculture can potentially be used as a sustainable solution for food security in the future. At present, the selection of aquaculture sites has not received much attention. Thus, this study aims to integrate a Geographic Information System and multi-criteria evaluation approach in identifying the potential sites for brackish aquaculture in the George Town Conurbation, Malaysia. ArcGIS 10.4 was used to perform site selection analysis together with the essential spatial data such as current land use, environmentally sensitive data, and soil quality that influence suitable sites selection for aquaculture. The selection was undertaken in ad hoc manners based on available land identified by aquaculture operators. The results indicated that the George Town Conurbation has a minimal potential site $(0.37 \%)$ for aquaculture sites. This minimal number results from the expansion of built-up areas towards urban fringe areas; hence less land becomes available for aquaculture. A reasonable buffer zone should be designated as a boundary between urban development and aquaculture to avoid land-use conflict between these two activities.
\end{abstract}

Keywords: aquaculture; brackishwater; GIS; MCE; site selection; food security; Malaysia

\section{Introduction}

The global human population is growing exponentially, securing the aquaculture sector's role in ensuring the world's food security as over 75\% of the world fisheries are considered fully exploited or overexploited [1]. The increased demand has resulted in an inevitable sector expansion, shown by the average production rate growth at $5.3 \%$ per year from 2001 to 2018 [2]. The growth is expected to intensify and increase production in the future, creating competition for finite space and resources with agricultural activities [2,3]. The sector's expansion includes increasing farms number, establishing farms in new geographical areas, increasing farm size, increasing cultivation (stocking density), and increasing farm productivity. Moreover, the intensification is obtained by the increased use of feeds, fertilizer, chemical inputs, land, and water use [4]. The expansion and intensification of the aquaculture sector are putting tremendous environmental pressures such as affluence and pesticides on the ecosystem goods and services as the presence of the farms alters the natural health of an ecosystem and disrupt the productivity of the nearby aquatic environment in a diverse and complex way $[5,6]$.

The presence of aquaculture farms can affect the natural ecosystem in several ways, e.g., water pollution is caused by poor input management [7-11], poor planning, and farm 
sitting [12-15]. Aquaculture farm affects its neighboring waterbody through eutrophication; a process caused by the excessive input of nutrients (e.g., phosphorus and nitrogen), and the waste secretion from the cultured animal. Sampantamit et al. [10] have reported that the intensification of aquaculture production is the main contributor to eutrophication in Thailand, predominantly due to the release of untreated wastewater and sewage sludge from the aquaculture farms. The accumulation of certain organic compounds, e.g., nitrogen, may acidify the water that indirectly causing significant damage to aquatic plants and animals [16]. A poor farm siting can degrade the natural environment, as demonstrated by Shahbudin et al. [15], where a part of mangrove forest in Kilim River, Malaysia, was converted to shrimp farms. The establishment of shrimp farms in mangrove forest areas has degraded the natural habitat, biodiversity, and nursery ground for marine animals [17]. Therefore, selecting a suitable location for aquaculture farming is critical for environmental impact mitigation measures and to ensure a successful aquaculture farm with unlimited future development and sustainability. At present, however, the location of the aquaculture farm was undertaken in an ad hoc manner based on the availability of land.

Traditionally, the location of aquaculture activities has been selected based on a combination of local demand and agroecology [16]. However, a poor aquaculture farm siting can lead to numerous environmental problems and fish farmers, such as lack of effective biosecurity, ecosystem service losses, lower production yield, social conflicts, risk financing, and resilience [15-17]. These problems can be minimized or prevented with more structured spatial planning. The location and intensity of aquaculture activity must sustainably balance conservation and economic return [17]. The potential site should be identified according to specific criteria and constraints, carefully considering social, economic, and environmental factors [18]. These criteria vary with location, species, system, and technology used, but it forms a basis for the aquaculture site selection tasks [19].

Radiarta et al. [20] listed several constraints in the aquaculture site selection task such as limited suitable sites, environmental impacts, and multi-use conflicts. These constraints are significant in spatial decision making, affecting the farmed product's quantity, quality, and profitability. Furthermore, it ensures the development of cost-efficient sustainable aquaculture whereby environmental impacts are mitigated, optimizing productivity and day-to-day management [19]. The selection of potential aquaculture sites can be identified using geographic information system (GIS), where GIS is defined as a system that captures, stores, analyses, and manages data associated with attributes spatially referenced to the earth [21]. Table 1 below shows the list of studies related to site selection problems.

Table 1. Summary of previous studies on aquaculture site selection analysis.

\begin{tabular}{|c|c|c|c|}
\hline $\begin{array}{c}\text { Related Studies on Site } \\
\text { Selection Task }\end{array}$ & Method Used & Types of Aquaculture & Criteria Included \\
\hline [22] & $\begin{array}{l}\text { GIS-based quantitative } \\
\text { land evaluation method }\end{array}$ & Inland & $\begin{array}{l}\text { Slope, land use type, soil thickness, soil } \\
\text { pH, elevation requirements, suitability of } \\
\text { soil type, soil texture, distance to sea } \\
\text { or/and other water sources, population } \\
\text { density, road distance, local markets, } \\
\text { and incubators. }\end{array}$ \\
\hline$[20,23]$ & $\begin{array}{l}\text { GIS-based multi-criteria } \\
\text { evaluation (MCE) method }\end{array}$ & Marine & $\begin{array}{l}\text { Sea temperature, chlorophyll, suspended } \\
\text { sediment, bathymetry, distance to town, } \\
\text { pier, and land-based facilities. Constraint } \\
\text { layers consist of the harbour, area near } \\
\text { town/industrial, and river mouth. }\end{array}$ \\
\hline [24] & $\begin{array}{l}\text { GIS-based multi-criteria } \\
\text { evaluation (MCE) }\end{array}$ & Marine & $\begin{array}{l}\text { Ammoniacal nitrogen, water depth, } \\
\text { water pH, DO, salinity, water movement, } \\
\text { soil type, turbidity, and plankton. }\end{array}$ \\
\hline
\end{tabular}


Table 1. Cont.

\begin{tabular}{|c|c|c|c|}
\hline $\begin{array}{l}\text { Related Studies on Site } \\
\text { Selection Task }\end{array}$ & Method Used & Types of Aquaculture & Criteria Included \\
\hline [25] & $\begin{array}{l}\text { GIS-based multi-criteria } \\
\text { evaluation (MCE) }\end{array}$ & Marine & $\begin{array}{l}\text { Distance from fishery port, distance from } \\
\text { river mouths, avoidance of shipping } \\
\text { zone, and buffer zone of the special } \\
\text { protection area. }\end{array}$ \\
\hline [26] & $\begin{array}{l}\text { GIS-based multi-criteria } \\
\text { evaluation (MCE) method }\end{array}$ & Inland & $\begin{array}{l}\text { Soil ( } \mathrm{pH} \text {, texture, organic matter), water } \\
\text { quality (temperature, } \mathrm{pH}, \mathrm{DO}, \mathrm{CO} 2, \\
\text { phosphate, nitrate, hardness, total alkalinity, } \\
\text { transparency), infrastructure (distance to } \\
\text { water source, road, market, hatchery) }\end{array}$ \\
\hline [27] & $\begin{array}{l}\text { GIS-based multi-criteria } \\
\text { evaluation (MCE) method }\end{array}$ & Marine & $\begin{array}{l}\text { Vegetation density, geology, } \\
\text { geomorphology, soil (texture, pH, clay } \\
\text { percentage, organic matter, sand } \\
\text { percentage, EC, fertility, depth), } \\
\text { infrastructure (distance to the sea, water } \\
\text { outlet channel, residential areas) land use, } \\
\text { height, slope, direction, distance to, } \\
\text { distance to roads, distance to the } \\
\text { industrial areas, distance to the } \\
\text { aquaculture farms. }\end{array}$ \\
\hline [28] & $\begin{array}{l}\text { Flexible Voroni cell-based } \\
\text { GIS model }\end{array}$ & Marine & $\begin{array}{l}\text { Sea surface temperature, chlorophyll- } \alpha \text {, } \\
\text { turbidity, and salinity }\end{array}$ \\
\hline [29] & $\begin{array}{l}\text { GIS-based multi-criteria } \\
\text { evaluation (MCE) method }\end{array}$ & Inland & $\begin{array}{l}\text { Environmental (slope, land use, clay } \\
\text { content of soil, pH soil, distance to } \\
\text { rivers), economic (distance to roads, } \\
\text { markets and inputs), Social (distance to } \\
\text { populations, protected areas), and } \\
\text { Physicochemical (pH, DO, temperature, } \\
\text { alkalinity, and hardness) }\end{array}$ \\
\hline [30] & $\begin{array}{l}\text { GIS-based DANP } \\
\text { (combination of } \\
\text { decision-making trial and } \\
\text { evaluation laboratory } \\
\text { method (DEEMATEL) and } \\
\text { analytical network } \\
\text { process (ANP)) }\end{array}$ & Inland & $\begin{array}{l}\text { Soil quality, water quality infrastructural } \\
\text { and land use, soil pH, soil texture, soil } \\
\text { organic matter, water temperature, water } \\
\text { pH, water DO, phosphate, nitrate, } \\
\text { hardness, water TDS, geology, distance } \\
\text { from the fault, elevation, slope, aspect, } \\
\text { land cover, distance from the protected } \\
\text { area, distance from water resources, } \\
\text { distance from the residential area, distance } \\
\text { from roads, distance from the market. }\end{array}$ \\
\hline
\end{tabular}

Table 1 provides a summary of selected existing studies demonstrating the application of GIS in performing site selection tasks for the location of aquaculture activities. Most of these studies have utilized the GIS-based multi-criteria evaluation (MCE) approach to identify suitable sites for aquaculture farms [20,24,26-30]. The study used GIS and MCDM by Mamat et al. [24] to identify suitable oyster farms is among the related study in Malaysia. In contrast, the other authors have demonstrated another approach, mostly a GIS-based combined approach for site selection tasks [22,28,30]. All previous studies have utilized GIS and remote sensing data in GIS analysis, showing that this technology has a significant role in the development and management of aquaculture in both aspects, geographically and spatially. Moreover, GIS application in this industry is able to reduce field sampling. It increases the spatial and temporal coverage of estimation, making GIS a powerful tool for the efficient and cost-effective management of sustainable aquaculture [18].

In achieving the decision objectives of the site selection task, multiple and conflicting criteria are considered. Hence, the MCE approach is used to enable a choice evaluation 
between alternatives [31], and the efficiency of the approach in various aquaculture industries has been demonstrated and reported in the existing studies listed in Table 1. For example, Nayak et al. [26] have demonstrated MCE and GIS integration in locating suitable aquaculture farm sites in Central Himalayas. Their work is among the earliest which evaluate aquaculture land suitability in a hilly region. Mamat et al. [24] utilized the MCE concept within a GIS environment in identifying a suitable site for oyster breeding in Terengganu. The research proposes a systematic, less time-consuming, and cheaper site selection method to the Department of Fisheries (DOF), Malaysia. However, the study excludes the social infrastructure criteria, which according to Cardia et al. [32], has a critical decision role in the task, such as minimize conflicts with other land users, preventing adverse impact to an environmentally sensitive area, and avoiding industrial areas which deteriorate the proximity water quality. Another example of the usage of MCE in GIS is the work by Radiarta et al. [20], where it is being used to identify suitable sites for Japanese scallop aquaculture in Funka Bay Hokkaido, Japan. The study shows that this method is not limited to inland aquaculture development but also marine aquaculture.

MCE has been modelled to determine the level of importance for each criterion against each other using a pairwise comparison matrix for solving conflicting criteria. MCE in land use analysis involves five steps: (1) problem identification (e.g., determining sites suitable for aquaculture farm), (2) selection of factors or criteria that reflects the character of the objectives (e.g., proximity to water source has a significant influence on aquaculture site selection, hence scored based on the level of importance), (3) score standardisation (e.g., each criterion have a value ranging from 1 to 3 so they are comparable), (4) attaching weights to each of the criteria selected using the pairwise comparison matrix, (5) weighted linear combination, where each criterion is presented in a raster digital map layer. The cells' standardised score is multiplied with their respective weights and summed to produce a composite map. The composite map is the suitability map containing cells with a value of 1 to 3 . The highest value indicates the most suitable location, and the low value indicates a non-suitable location.

Although Malaysia is among the top five aquaculture producer countries in Southeast Asia, a proper aquaculture spatial planning is lacking in the aquaculture industry in Malaysia, e.g., DOF is still utilizing the conventional method of site selection and in-situ water quality monitoring [24]. Likewise, to date, the existing literature on GIS application for the aquaculture industry in Malaysia is scarce compared to the other countries in Southeast Asia. Hence, we can say that the utilisation of GIS technology in aquaculture management and development in Malaysia is minimal. The practice of conventional methods not only is time-consuming and inefficient, but also it might impede the future development of the aquaculture industry in the country. Therefore, this paper presents a GIS-based multi-criteria evaluation (MCE) that uses remote sensing and land use data to identify the most suitable sites for inland aquaculture farms in Georgetown Conurbation. This study integrated GIS and MCE approach by using ArcGIS 10.4 and the essential spatial data, including current land use, environmentally sensitive data, and soil quality that influence suitable sites for aquaculture. The systematic approach used in this study can provide assistance for maximizing sustainability by exploring only suitable sites rather than wasting land for unsuitable sites.

\section{Materials and Methods}

\subsection{George Town Conurbation}

The George Town Conurbation have an area of approximately $3938 \mathrm{~km}^{2}$ (see Figure 1). The main reason for selecting George Town Conurbation as the study area is that Penang's aquaculture sectors' average annual growth rate between 1995 and 2015 is remarkable, $8.2 \%$ and $23 \%$ in production and values. Penang's food fish production showed the secondhighest wholesale value in Malaysia, with aquaculture contributing over $54 \%$ to Malaysia's food fish production (58,736 metric tonnes, valued at RM1090.6 mil). However, being the second smallest state in Malaysia hinders the expansion of the sector. Hence, it is 
predicted that the expansion of the industry will be focused on its neighbouring states. The second reason for selecting George Town Conurbation is data availability. Data availability is crucial in spatial modelling, as data input and database creation are costly and timeconsuming. The Geoinformatics Unit, Universiti Sains Malaysia have collected digital data sets for George Town Conurbations. These include digital map data sets of roads, rivers, and land use for 2017-2018. The data sets described above form the primary digital data sources used in this study.

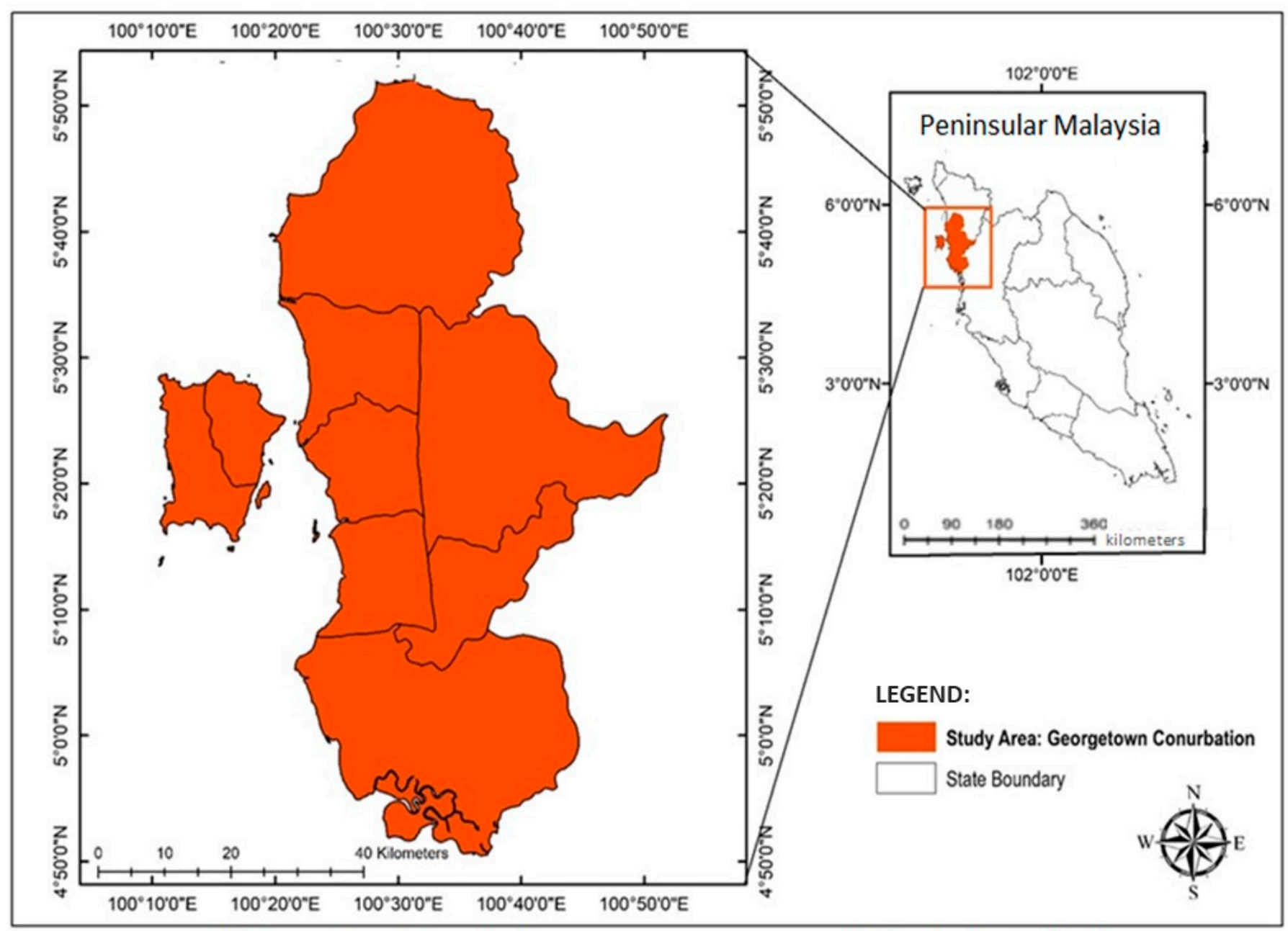

(a) George Town Conurbation

(b) Peninsular Malaysia

Figure 1. The study area.

\subsection{Data}

Digital elevation model (DEM) data for the study area were obtained from the United States Geological Survey [33] acquired on 20 June 2019. The spatial resolution of the DEM is $30 \mathrm{~m}$. FAO digital soil map is used in the research to map the soil quality in the George Town Conurbation area. Land use data provided by The Geoinformatics Units, USM is being used in this research. All digital data were processed within the GIS software, ArcMap for windows (version 10.4), developed by Environmental System Research Institute Inc., Redlands, CA, USA. All map layers are transformed into WGS 1984 coordinates projection, following the FAO Soil Map coordinates projection. For the distance scale, the unit meter was used and defined in the software system. The procedure followed in modelling the land suitability for fisheries development is presented in Figure 2. 


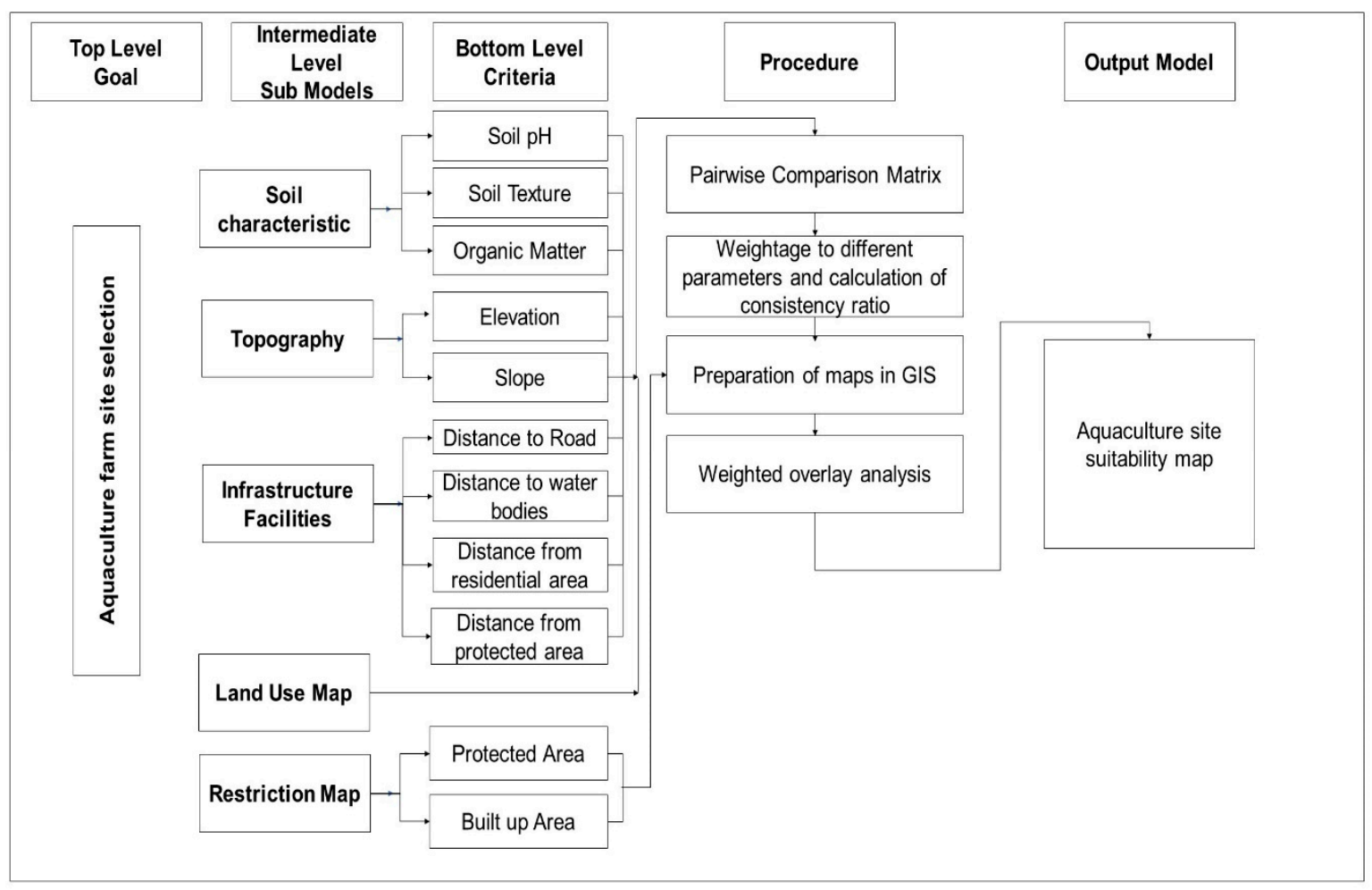

Figure 2. Schematic diagram of the modelling procedure for potential aquaculture farm sites.

\subsection{Spatial Analysis-Modelling Methodology}

The approach is comprised of five steps. The first step involves setting the objective, which is to determine suitable sites for aquaculture activity. The second step involves identifying criteria and constraints to use in selecting aquaculture sites. This analysis is important for preparing criteria and constraints conducted within a raster environment, and all the layers are converted in raster with the size of $30 \mathrm{~m}$ before analysis. Soil quality parameter such as $\mathrm{pH}$, soil texture and soil organic matter is obtained from the FAO Soil Map of the World [34]. The slope and elevation data are extracted from the DEM SRTM $30 \mathrm{~m}$. Land use data are obtained from the Geoinformatics Unit, USM, to extract the water bodies, road, residential area and protected region information are obtained. Although there are many criteria to be considered in aquaculture site selection, due to data limitation, nine (9) essential criteria listed by $[26,30,35]$ were chosen. The third step involves standardising the suitability score for all criteria. The suitability scores for this study are based on the FAO guideline [32], where value one (1) is assigned for the not suitable cell, and value three (3) is assigned for the most suitable cell. Figure 2 shows the schematic diagram of the modelling procedure for the identification of potential aquaculture sites. The criteria considered in this study with its' suitability rating are shown in Table 2.

Suitability analysis in this study is conducted using the suitability Equation (1).

$$
S=\sum_{i=1}^{n} w_{i} c_{i}
$$

where $S$ is the suitability score, $w_{i}$ is the weight of each criterion, $c_{i}$ is the criterion score, and $n$ is the criteria used in the task (here, $n=9$ ). The suitability equation is used to integrate the trade-offs between various factors and calculate an overall weighted suitability score for each evaluation unit. ArcMap 10.4 model builder tool is used to develop the suitability model for identifying the potential site for aquaculture farms. 
Table 2. The suitability rating for the aquaculture site selection criteria $[26,30,32,35]$.

\begin{tabular}{|c|c|c|c|c|}
\hline \multirow[b]{2}{*}{ Criteria } & \multicolumn{3}{|c|}{ Suitability Rating and Score } & \multirow[b]{2}{*}{ Description } \\
\hline & $\begin{array}{c}3 \\
\text { (Most Suitable) }\end{array}$ & $\begin{array}{c}2 \\
\text { (Moderately Suitable) }\end{array}$ & $\begin{array}{c}1 \\
\text { (Not Suitable) }\end{array}$ & \\
\hline $\begin{array}{l}\text { Soil Characteristic } \\
\text { Soil pH } \\
\text { Soil texture (texture) } \\
\text { OM (\% of carbon) }\end{array}$ & $\begin{array}{l}6.5-8.5 \\
\text { Clay loam } \\
\quad<1\end{array}$ & $\begin{array}{l}5.5-6.5 \text { and } 8.5-9.0 \\
\text { Sandy clay } \\
1-2\end{array}$ & $\begin{array}{c}<5.5 \text { and }>9.0 \\
\text { Loam, sand } \\
\quad>2\end{array}$ & $\begin{array}{c}\text { Fishpond requires low salinity } \\
\text { and natural } \mathrm{pH} \text { with low } \\
\text { water infiltration }\end{array}$ \\
\hline $\begin{array}{l}\text { Soil Condition } \\
\text { Elevation }(\mathrm{m}) \\
\text { Slope }(\%)\end{array}$ & $\begin{array}{l}0-5 \\
0-2\end{array}$ & $\begin{array}{l}5-10 \\
2-5\end{array}$ & $\begin{array}{l}>10 \\
>5\end{array}$ & $\begin{array}{l}\text { The moderate slope is the most } \\
\text { suitable for aquaculture pond }\end{array}$ \\
\hline \multicolumn{5}{|l|}{ Infrastructural facilities } \\
\hline Distance to road (m) & $<500$ & 500-1000 & $>1000$ & \multirow[t]{2}{*}{$\begin{array}{l}\text { Proximity to existing } \\
\text { infrastructure provides easy } \\
\text { access to the aquaculture sites }\end{array}$} \\
\hline $\begin{array}{c}\text { Distance from protected } \\
\text { area }(\mathrm{m})\end{array}$ & $>5000$ & $4000-5000$ & $<4000$ & \\
\hline $\begin{array}{l}\text { Distance from residential } \\
\text { area }(\mathrm{m})\end{array}$ & $>4000$ & $2000-4000$ & $<2000$ & $\begin{array}{l}\text { Aquaculture should not be too } \\
\text { close to residential and } \\
\text { protected areas to avoid } \\
\text { environmental problems } \\
\text { such as odour }\end{array}$ \\
\hline Land Use & & & & \\
\hline Land Use & Vacant land & Agriculture & $\begin{array}{l}\text { Built-up area, forest, } \\
\text { water bodies }\end{array}$ & Vacant land is less expensive \\
\hline
\end{tabular}

Fourth, weight for each criterion was assigned based on the interview conducted with three academicians who have expertise in aquaculture practices. The experts were asked to fill in the form using a pairwise comparison matrix as shown in Table 3, where the scoring range from $1 / 9$ (least important) to 9 (most important). Then, their assessments were evaluated using the median method to determine the pairwise comparison matrix, as shown in Table 4.

Table 3. The relative importance of two criteria.

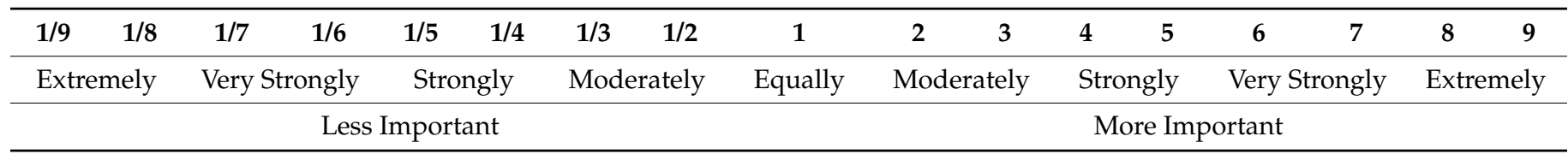

A consistency ratio (CR), [CR = Consistency Index (CI)/Random Consistency Index $]$ of less than 1 shows a consistent comparison between the criteria and is considered acceptable [36]. The random consistency index (RI) is different for different $n$ values, where $\mathrm{n}$ is the number of criteria. The RI value for different $n$ is presented in Table 5 , and CI was calculated as follows:

$$
C I=\frac{(\lambda \max -n)}{(n-1)}
$$

where, $\lambda \max =\sum$ of the products between each element of the priority vector and column totals, and $n=$ number of criteria. 
Table 4. Pairwise comparison matrix and the weight assigned for each criterion.

\begin{tabular}{|c|c|c|c|c|c|}
\hline Criteria & Soil pH & Soil Texture & $\begin{array}{l}\text { Soil Organic } \\
\text { Matter }\end{array}$ & \multicolumn{2}{|l|}{ Weight } \\
\hline \multicolumn{6}{|l|}{ Soil quality } \\
\hline Soil pH & 1 & & & \multicolumn{2}{|l|}{0.3} \\
\hline Soil texture & $1 / 2$ & 1 & & \multicolumn{2}{|l|}{0.2} \\
\hline Soil organic matter & 3 & 2 & 1 & \multicolumn{2}{|l|}{0.5} \\
\hline Consistency ratio & \multicolumn{5}{|c|}{0.031} \\
\hline \multicolumn{6}{|l|}{ Soil Condition } \\
\hline Criteria & Elevation & Slope & & \multicolumn{2}{|l|}{ Weight } \\
\hline Elevation & 1 & & & \multicolumn{2}{|c|}{0.3} \\
\hline Slope & 2 & 1 & & 0.7 & \\
\hline Consistency ratio & \multicolumn{5}{|c|}{0.000} \\
\hline \multicolumn{6}{|l|}{ Infrastructure Facilities } \\
\hline Criteria & $\begin{array}{c}\text { Distance to } \\
\text { Water Source }\end{array}$ & $\begin{array}{c}\text { Distance to the } \\
\text { Road }\end{array}$ & $\begin{array}{l}\text { Distance from } \\
\text { Protected Area }\end{array}$ & \multirow[t]{2}{*}{$\begin{array}{c}\text { Distance from } \\
\text { Residential Area }\end{array}$} & Weight \\
\hline Distance to water source & 1 & & & & 0.4 \\
\hline Distance to road & $1 / 2$ & 1 & & & 0.3 \\
\hline Distance from protected area & 2 & 2 & 1 & \multirow{3}{*}{1} & 0.2 \\
\hline Distance from residential area & $1 / 5$ & $1 / 5$ & 1 & & 0.1 \\
\hline Consistency Ratio & & & -0.220 & & \\
\hline \multicolumn{6}{|l|}{ Overall } \\
\hline Criteria & $\begin{array}{c}\text { Soil } \\
\text { Characteristic }\end{array}$ & $\begin{array}{l}\text { Infrastructural } \\
\text { Facilities }\end{array}$ & Land Use & Soil Condition & Weight \\
\hline Soil Characteristic & 1 & & & & 0.2 \\
\hline Infrastructural facilities & $1 / 3$ & 1 & & & 0.2 \\
\hline Land Use & 3 & 4 & 1 & & 0.4 \\
\hline Soil Condition & 2 & $1 / 2$ & $1 / 2$ & 1 & 0.2 \\
\hline Consistency Ratio & & & -0.7407 & & \\
\hline
\end{tabular}

Table 5. Random consistency index (RI) [36].

\begin{tabular}{ccccccccccc}
\hline $\boldsymbol{n}$ & $\mathbf{1}$ & $\mathbf{2}$ & $\mathbf{3}$ & $\mathbf{4}$ & $\mathbf{5}$ & $\mathbf{6}$ & $\mathbf{7}$ & $\mathbf{8}$ & $\mathbf{9}$ & $\mathbf{1 0}$ \\
\hline $\mathrm{RI}$ & 0 & 0 & 0.58 & 0.90 & 1.12 & 1.24 & 1.32 & 1.41 & 1.45 & 1.49 \\
\hline
\end{tabular}

Based on Table 4, the consistency ratio calculated for soil quality, infrastructural facilities and overall are $0.065,-0.220$, and 0.087 , respectively. All CR were less than $10 \%$, as recommended by Saaty [36], signifying a small probability that the weights were developed by chance. Data are obtained from previous studies undertaken at Universiti Sains Malaysia. Geoprocessing was undertaken to ensure all data were in the same format and scale. ArcGIS was used for data processing and analysis. All the data layers need to be prepared before undergoing the weighted analysis. The Euclidean distance map of water bodies, roads, residential areas and protected areas is generated, enabling proximity analysis for the study. The map produced were restricted from being identified as a potential site for an aquaculture farm. Data standardization is required to enable a comparison between all the map layers. This process will produce a final suitability map for potential aquaculture sites retained within the 1-3 suitability score range. The highest score signifies the most suitable location, and the lowest score signifies the non-suitable location for aquaculture farm development. All layers are multiplied with their respective weight and summed in the weighted overlay process, producing a suitability map. Equation (1) is used to produce the final suitability map; shown below is the usage of Equation (1) in the study for soil and infrastructure suitability map: 


$$
\begin{gathered}
\text { Soil }_{\text {Suitability }}=\left(\text { Soil }_{p H} \times 0.1\right)+\left(\text { Soil }_{\text {texture }} \times 0.1\right)+\left(\text { Soil }_{O M} \times 0.3\right)+\left(\text { Soil }_{\text {slope }} \times 0.2\right)+\left(\text { Soil }_{\text {elev }} \times 0.2\right) \\
\text { Infra }_{\text {suitability }}=\left(\text { Infra }_{\text {water }} \times 0.4\right)+\left(\text { Infra }_{\text {road }} \times 0.3\right)+\left(\text { Infra }_{\text {protected area }} \times 0.2\right)+\left(\text { Infra }_{\text {residential }} \times 0.1\right)
\end{gathered}
$$

Then, based on Equation (1) above, the study used overlay techniques of ArcGIS 10.4 to combine all criteria and constraints (restriction map) to generate the final suitability map. The approach allows potential sites to be identified. The procedure is shown in Equation (5) below.

$$
\text { Site Suitability }=\left(\left(\text { Soil }_{\text {suitability }} \times 0.3\right)+\left(\text { Infra }_{\text {suitability }} \times 0.1\right)+\left(\text { Landuse }_{\text {suitability }} \times 0.6\right)\right) \times \text { Restriction Map }
$$

Finally, selecting the best potential sites among the highly suitable sites is conducted based on the size of the suitable area. As suggested by the Penang State of Forestry Department [37], the minimum size for a commercial aquaculture farm is 20 ha, however considering a future expansion and expert opinion, the best potential sites are those with more than 35 ha [38].

\subsection{Model Validation}

Model validation is vital for quality control of specific data and for testing the output of the models [20]. The model validation was carried out by comparing the existing aquaculture farm with the predicted suitable site location. The model is considered acceptable when more than $60 \%$ of the existing farm lies in a suitable site identified through the analysis.

\section{Results}

Remote sensing and GIS were used to identify the appropriate sites for establishing aquaculture farms in George Town Conurbation. According to the AHP model, soil organic matter has the highest importance (30\%) for soil quality suitability maps than other soil quality parameters. In the case of infrastructure facilities, water sources scored the highest importance $(40 \%)$ in comparison to the other parameters included. Land use has the most critical decision role $(60 \%)$ compared to soil quality $(30 \%)$ and infrastructural facilities $(10 \%)$ for aquaculture development in the study area. Thematic maps were prepared for all the criteria chosen and reclassified into a map with cell values ranging from 1 to 3. Finally, soil quality and infrastructure facilities suitability were prepared based on Equations (3) and (4), as presented in Figures 3-5.

For land-use classification, built-up area, water bodies and forest are classified into a non-suitable location to be considered in identifying a suitable site for aquaculture farm establishment. These three types of land use encompass about $93.10 \%$ of the total area in the study area, signifying that $93.10 \%$ of the area in George Town Conurbation prohibits aquaculture farm development. However, there are still trade-offs for water bodies and built-up areas depending upon each criterion's weightage. The forest covers about $1.28 \%$ of the area's total area, signifying that this area is strictly prohibited from any development. Since 1972, the Penang State Forestry Department [37] has never granted anyone a license for any economic development in the forest area. The Department of Town and Country Planning Malaysia recommended that a green buffer of $5000 \mathrm{~m}$ be allocated around the reserved forest [38]. This green buffer forbids the development of road, drain and trench, river and lake, car park, open space, service building and small agriculture plot including aquaculture pond. A buffer of $4000 \mathrm{~m}$ from the residential area is required; to prevent sewage from seeping into the aquaculture pond and due to space limitation and demand. Domestic waste in urban areas can significantly impact aquaculture farms [22]. Vacant land is classified as the most suitable land for aquaculture development. The main reason is that the installation cost will be minimised due to the absence of an intense land clearing 
process. The same procedure is applied with the land use map, where a thematic map is created then reclassified into suitability scale, as shown in Figures 6 and 7.

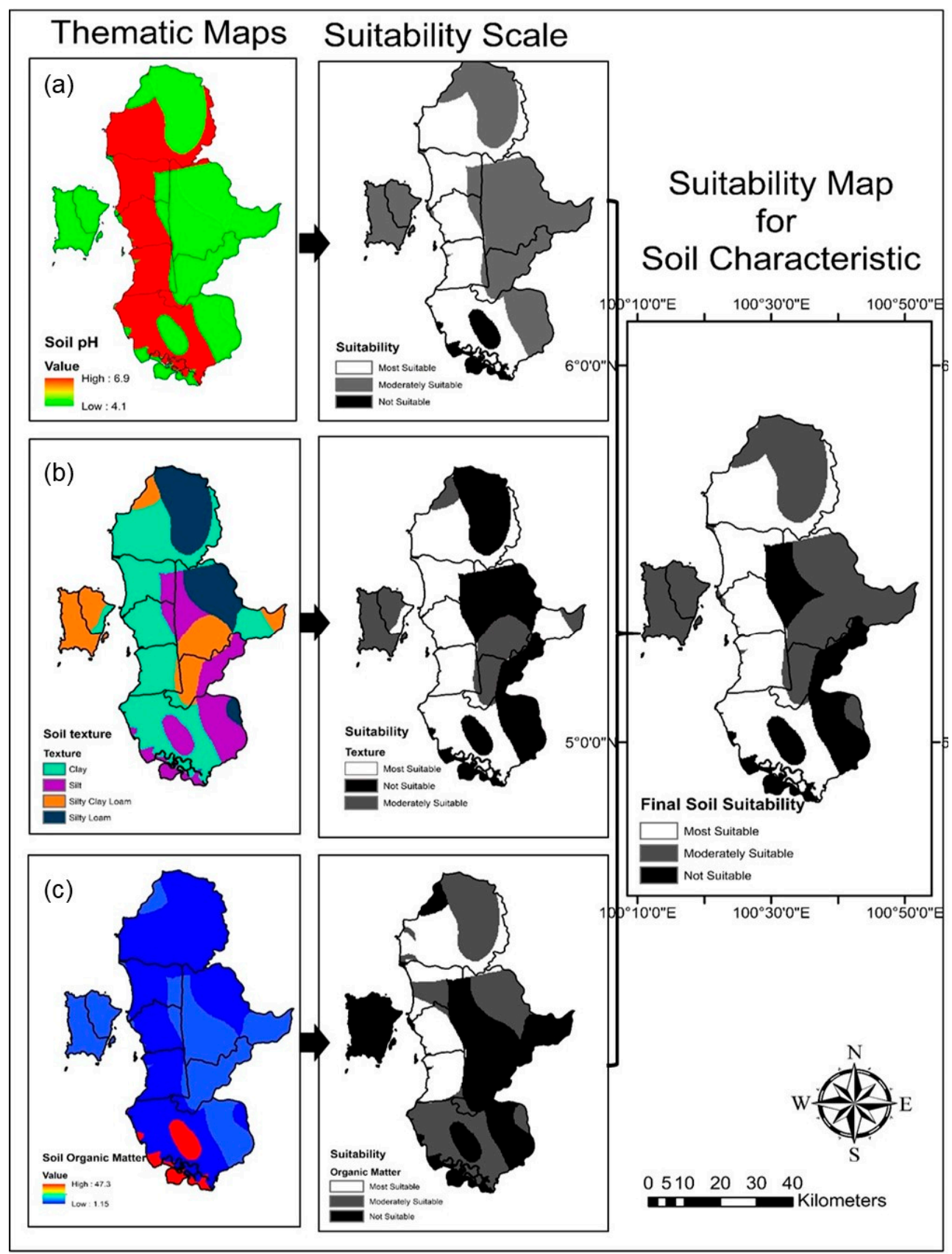

Figure 3. Process of producing a suitability map for soil characteristics from (a) soil $\mathrm{pH}$, (b) soil texture, and (c) soil organic matter. 


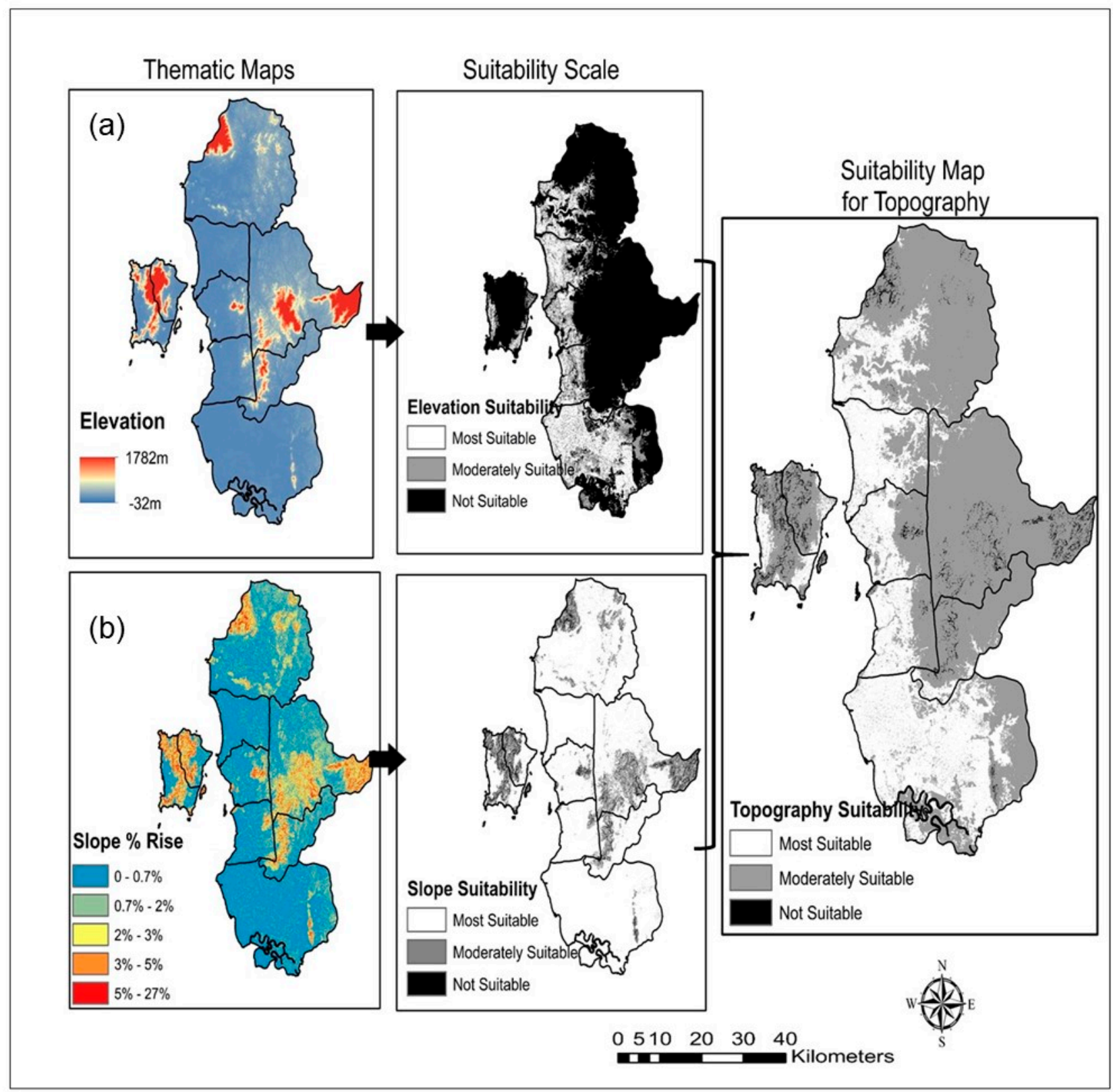

Figure 4. Process of producing a suitability soil condition map from (a) elevation, and (b) slope rise. 


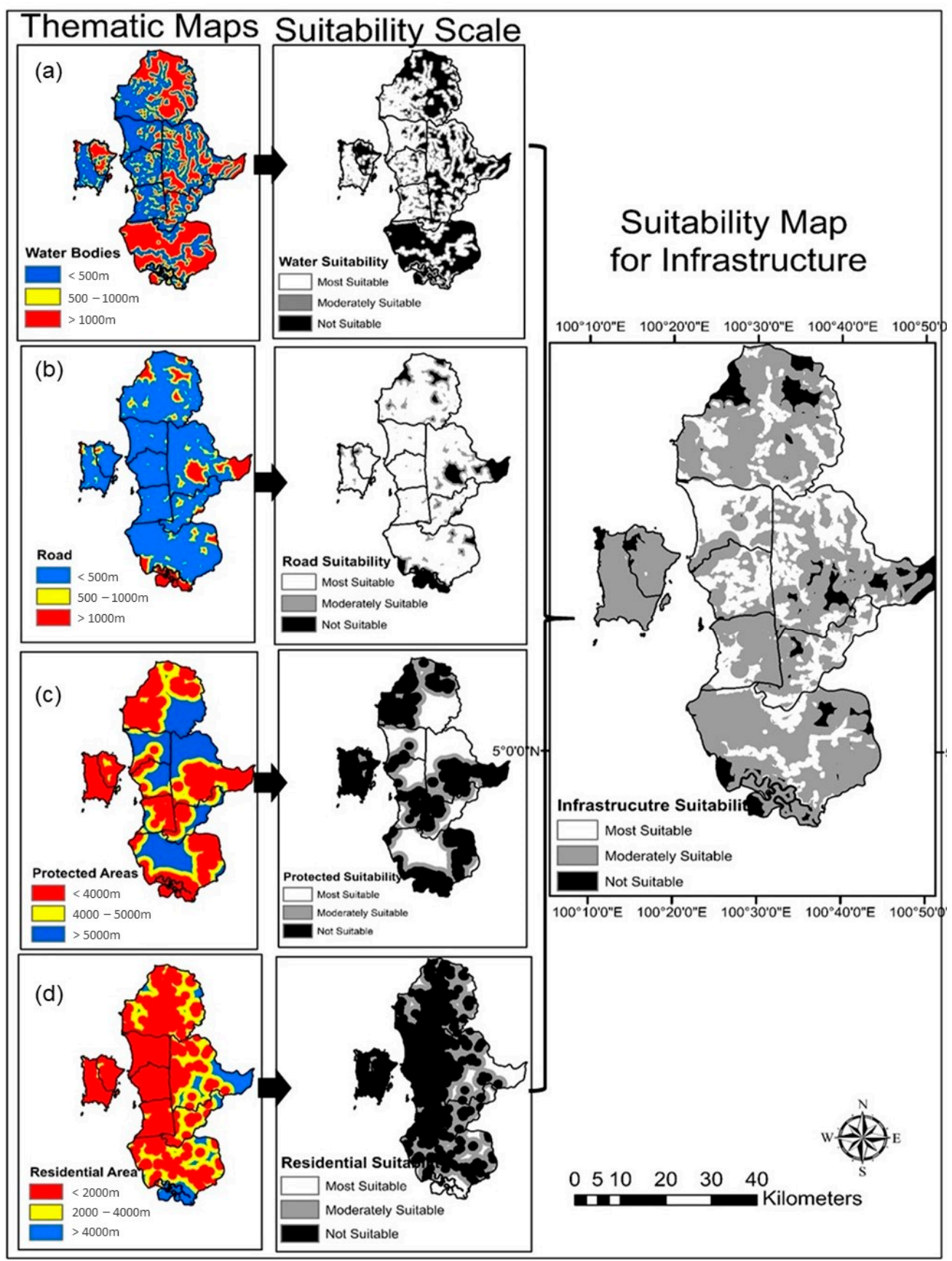

Figure 5. Process of producing infrastructure facilities suitability map from (a) water bodies, (b) road, (c) protected area, and (d) residential area. 


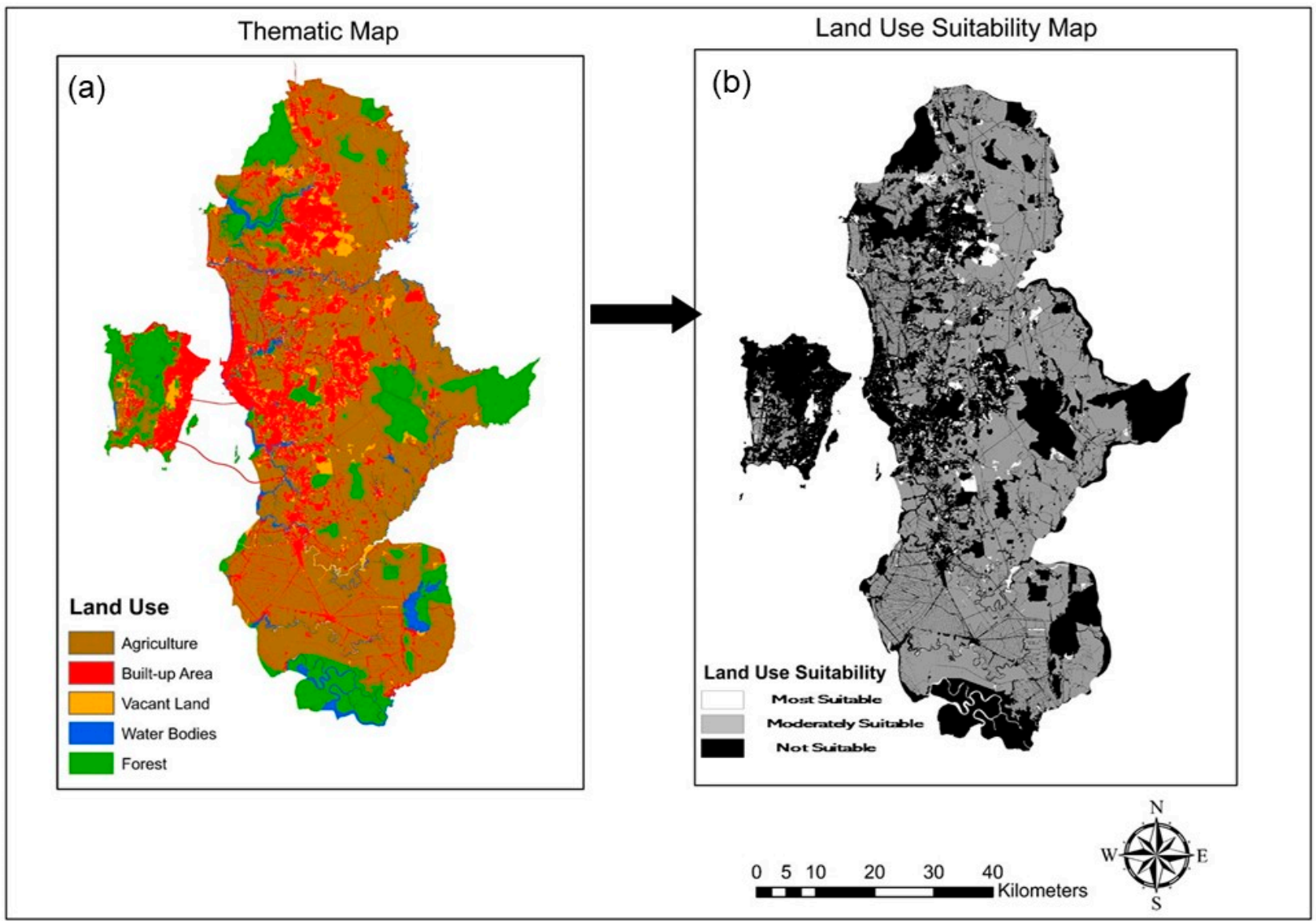

Figure 6. (a) Land use and (b) land use suitability map in the George Town Conurbation.

The final suitability map combines all the suitability map, soil suitability, infrastructure facilities suitability and land use suitability. The process of combination is constructed following Equation (5) and presented in Figure 8.

Based on Figure 8a, out of the total area of 1690166.6 ha of the George Town Conurbation region, only 6229.4 ha $(0.37 \%)$ scores most suitable for aquaculture development. Further selection was made based on the size of the area. As mentioned earlier, the size of the potential site should be than 35 ha to accommodate future needs [37]. Based on the analysis, which comprises $0.31 \%$ of the total area in the region. The highlighted site is presented in Figure $8 \mathrm{~b}$ above. Model validation showed that around $65 \%$ of the existing ponds are in the most suitable areas while the others fall under moderately suitable areas. As indicated in Figure $8 \mathrm{~b}$ above, the most suitable sites are in the northern part of the study area and have good access to the transport network and major town. Other areas are scattered near Bukit Mertajam of Penang, which has a population of more than 1.7 million $[3,6]$. 


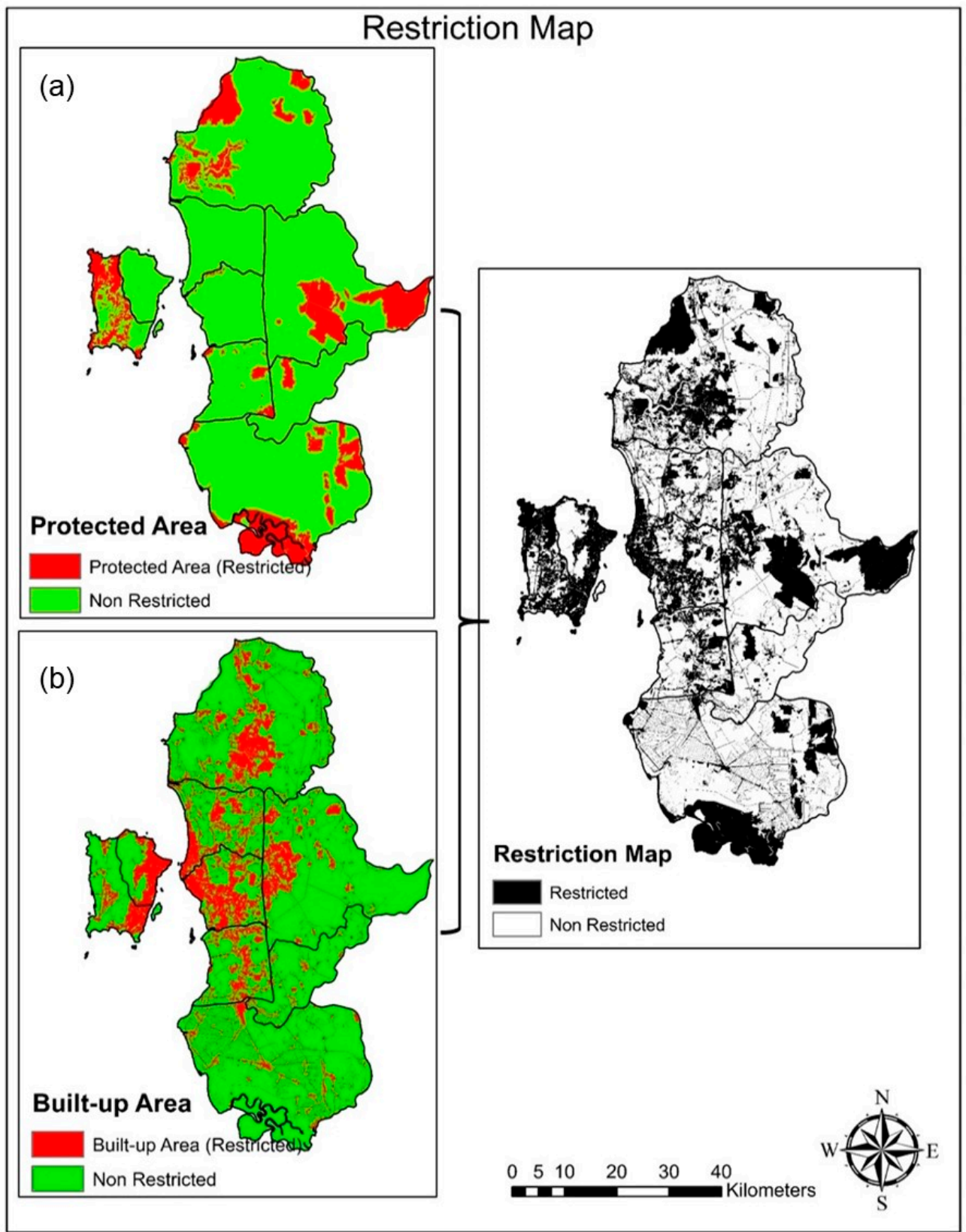

Figure 7. Restriction map generated from (a) protected area and (b) built-up area. 

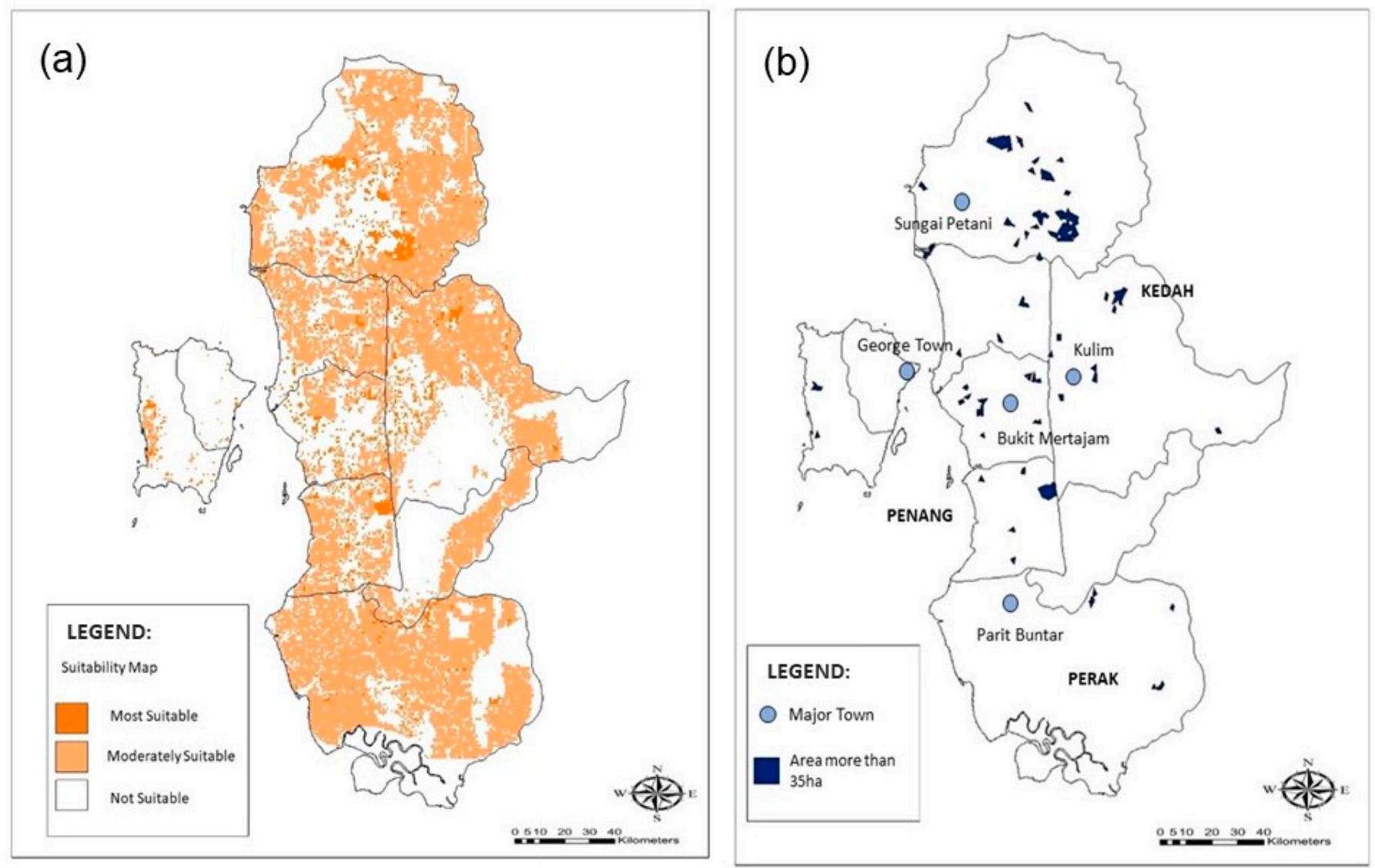

Figure 8. (a) Final suitability map for aquaculture development in George Town Conurbation and (b) most suitable sites with a size of more than 35 ha.

\section{Discussion}

The growing global population has increased the demand for protein triggering the aquaculture industry's expansion. Due to the industry's rapid expansion, the unplanned and unregulated farm has been established at the cost of environmental stress and subsequent yield failure in the aquaculture farm. In Malaysia, for example, site selection for aquaculture is mainly done using an ad hoc approach based on availability [24,37]. This approach has resulted in environmental impacts such as odour and land-use conflicts, which negatively impacts the community nearby. Furthermore, inland aquaculture naturally competes for space demand with other land users, particularly urbanisation, industry, tourism, and agriculture [39]. Hence, structured spatial planning for aquaculture development should be prioritised to avoid interferences and conflicts of space and water [40]. Proper spatial planning plays a vital role in aquaculture expansion, operation and diversification, affecting success and sustainability and rationalising the land [41].

Several authors have highlighted the importance of integrating RS, GIS, and MCE as a competent tool in assisting strategic decision making for aquaculture's sustainable development. The implementation of MCE within GIS is used by Mamat et al. [24] to evaluate land suitability for oyster aquaculture in Terengganu, Malaysia; Mustafa et al. [42] utilises GIS technology in the characterisation of land and its suitability for Tilapia farming in Maros Regency, Indonesia; Estigade et al. [43] uses GIS and RS in water environment suitability evaluation for floating cages in Lampung and Hurun Bay. They also conducted a questionnaire survey to obtain water suitability characteristic information for floating net cages. However, the main problem with site selection for aquaculture is the lack of baseline information on the physicochemical and topographic conditions and existing land use patterns [27]. 
A suitable aquaculture site is affected by many aspects, including environmental (physical, biological and chemical) and socio-economic factors. Due to limited data availability, the site selection model used in this study only focused on several parameters such as soil texture, organic matter soil, soil $\mathrm{pH}$, elevation, slope and some infrastructural facilities. Combining these parameters within a GIS environment enable relevant analysis for decision-makers than one based on individual parameters alone. Despite the extent of favourable locations, the GIS-based model does not imply actual estimates of carrying capacity (either physical, production, ecological or social) within the region but instead identifies locations where there may be maximised for the aquaculture activities [44]. This effort has maintained sustainability by reducing the exploration of unsuitable sites that may impact the environment. Logically, a separate development needs to be located some distance apart to minimise the potential cumulative impacts.

This study is lacking in terms of social factors. It is shown in [25] that indigenous knowledge can support the decision-making process, especially for less developed countries where indigenous knowledge is comprehensively handled and transmitted by communities. Therefore, the MCE method, combined with indigenous knowledge, can assist in the sites selection process by providing stakeholder engagements. Focus group discussion, interviews, or questionnaire surveys should be added to improve the weightage analysis accuracy and ensure an objective criteria selection specific for the study area. The social factor will also incorporate public opinion on an aquaculture farm in a specific location; hence, it would be more valuable.

Considering soil condition in the George Town Conurbation for aquaculture observed $6.7 \%$ area with most suitable whereas around $88.2 \%$ was moderately suitable. It seems that the study area is moderately suitable for inland aquaculture in terms of soil features. A similar trend is shown by infrastructure facilities suitability, where $0.5 \%$ of areas with the most suitable aquaculture location and $99 \%$ with moderately suitable. The overall most suitable area for aquaculture potential sites is $0.37 \%$; it is logical as the study area are experiencing an expansion of built-up areas towards urban fringe areas; hence less land become available for aquaculture area. This study reveals that even though Penang is one of Malaysia's primary aquaculture producers, thorough and structured spatial planning is essential for this industry's future in Penang. A reasonable buffer zone should be designated as a boundary between urban development and aquaculture to avoid land-use conflict between the two activities. Although the approach used manages to show potential sites for aquaculture, it should be noted that the robustness of the result has not been analysed. Therefore, further study should include sensitivity analysis such as using a jackknifing approach which can potentially be used to evaluate the change in comparison matrix weights on the result.

\section{Conclusions}

The application of GIS in identifying the suitable potential sites for aquaculture farms shows that it works effectively. As expected, only a small number of areas $(0.37 \%)$ in the Georgetown Conurbation had high suitability scores for the aquaculture farm establishment. In the George Town Conurbation for aquaculture, soil conditions were most favourable in $6.7 \%$ of the area, while somewhat suitable in $88.2 \%$. In terms of soil characteristics, the research area appears to be relatively favourable for inland aquaculture. Infrastructure facility suitability follows a similar pattern, with $0.5 \%$ of places having the most favourable aquaculture setting and $99 \%$ having moderately suitable. The small number of suitable sites can be explained by the current urban expansion of the study area, hence less land suitable for aquaculture farms. GIS is indeed a powerful modelling tool for site selection decision making. The usefulness of GIS will be more significant as data availability increases. 
Author Contributions: Conceptualization, P.N.A.B. and N.S.; methodology, P.N.A.B. and N.S.; software, P.N.A.B.; validation, P.N.A.B., N.S. and M.A.M.; formal analysis, P.N.A.B.; writing-original draft preparation, P.N.A.B. and N.S.; writing—review and editing, M.A.M. and M.L.T.; visualization, P.N.A.B. and M.A.M.; supervision, N.S. and N.W.C.; project administration, N.S., M.L.T. and N.W.C.; funding acquisition, N.W.C. and M.L.T. All authors have read and agreed to the published version of the manuscript.

Funding: The financial support of the Long-Term Research Grant Scheme (LRGS/1/2018/USM/01/1/5) (203/PHIMANITI/67215003), which is supported by the Ministry of Higher Education Malaysia.

Institutional Review Board Statement: Not applicable.

Informed Consent Statement: Not applicable.

Data Availability Statement: The data presented in this study are available on request from the corresponding author.

Acknowledgments: The authors also acknowledge the United States Geological Survey, FAO, Plan Malaysia and Malaysia Geospatial Data Infrastructure (MyGDI), for supplying geospatial data to this study.

Conflicts of Interest: The authors declare no conflict of interest.

\section{References}

1. Naylor, R.L.; Hardy, R.W.; Buschmann, A.H.; Bush, S.R.; Cao, L.; Klinger, D.H.; Little, D.C.; Lubchenco, J.; Shumway, S.E.; Troell, M. A 20-year retrospective review of global aquaculture. Nature 2021, 591, 551-563. [CrossRef]

2. Food and Agriculture Organization-FAO. The State of World Fisheries and Aquaculture 2020: Sustainability in Action. Available online: https:/ / doi.org/10.4060/ ca9229en (accessed on 19 March 2020).

3. Samat, N.; Mahamud, M.A. Simulating urban growth in the george town conurbation. J. Fundam. Appl. Sci. 2017, 9, 144-156.

4. White, P. Aquaculture Pollution: An Overview of Issues with a Focus on China, Vietnam, and the Philippines; World Bank: Washington, DC, USA, 2017; Volume 52.

5. Nurfadillah, N.; Dewiyanti, I.; Yunizar, S.; Mellisa, S.; Arisa, I.I. Suitability analysis of aquaculture ponds based on primary productivity parameters in Mangrove Area of Banda Aceh. IOP Conf. Ser. Earth Environ. Sci. 2020, 493, 012019. [CrossRef]

6. Samat, N.; Mahamud, M.A. Urbanisation in the George Town conurbation and its impact to the environment. Int. J. Environ. Eng. 2018, 9, 240-253. [CrossRef]

7. Edwards, P. Aquaculture environment interactions: Past, present and likely future trends. Aquaculture 2015, 447, 2-14. [CrossRef]

8. Kokou, F.; Fountoulaki, E. Aquaculture waste production associated with antinutrient presence in common fish feed plant ingredients. Aquaculture 2018, 495, 295-310. [CrossRef]

9. Mungkung, R.; Aubin, J.; Prihadi, T.H.; Slembrouck, J.; Van Der Werf, H.M.G.; Legendre, M. Life Cycle Assessment for Environmentally Sustainable Aquaculture Management: A Case Study of Combined Aquaculture Systems for Carp and Tilapia. J. Clean. Prod. 2013, 57, 249-256. [CrossRef]

10. Sampantamit, T.; Ho, L.; Lachat, C.; Sutummawong, N.; Sorgeloos, P.; Goethals, P. Aquaculture production and its environmental sustainability in thailand: Challenges and potential solutions. Sustainability 2020, 12, 2010. [CrossRef]

11. White, P.G. Environmental consequences of poor feed quality and feed management: On-farm feeding and feed management. Aquaculture 2013, 100, 553-564.

12. Crawford, C.; Macleod, C. Predicting and assessing the environmental impact of aquaculture. In New Technologies in Aquaculture: Improving Production Efficiency, Quality and Environmental Management; Woodhead Publishing Limited: Oxford, UK; Cambridge, UK; New Delhi, India, 2009; pp. 679-706.

13. Gentry, R.R.; Lester, S.E.; Kappel, C.V.; White, C.; Bell, T.W.; Stevens, J.; Gaines, S.D. Offshore aquaculture: Spatial planning principles for sustainable development. Ecol. Evol. 2017, 7, 733-743. [CrossRef] [PubMed]

14. Lester, S.E.; Stevens, J.M.; Gentry, R.R.; Kappel, C.V.; Bell, T.W.; Costello, C.J.; Gaines, S.D.; Kiefer, D.A.; Maue, C.C.; Rensel, J.E.; et al. Spatial planning makes room for offshore aquaculture in crowded coastal waters. Nat. Communed. 2018, 9, 1-13. [CrossRef] [PubMed]

15. Shahbudin, S.; Zuhairi, A.; Kamaruzzaman, B.Y. Impact of Coastal development on mangrove cover in Kilim River, Langkawi Island, Malaysia. J. For. Res. 2012, 23, 185-190. [CrossRef]

16. Luo, Z.; Hu, S.; Chen, D. The trends of aquacultural nitrogen budget and its environmental implications in China. Sci. Rep. 2018, 8, 1-9. [CrossRef] [PubMed]

17. Food and Agriculture Organization-FAO. Mangroves of Asia 1980-2005: Country reports. In Forest Resources Assessment Programme Working Paper; FAO: Rome, Italy, 2007; Volume 137.

18. Radiarta, I.N.; Saitoh, S.I.; Yasui, H. Aquaculture site selection for Japanese kelp (Laminaria japonica) in Southern Hokkaido, Japan, using satellite remote sensing and GIS-based models. ICES J. Mar. Sci. 2011, 68, 773-780. [CrossRef] 
19. Falconer, L.; Middelboe, A.L.; Kaas, H.; Ross, L.G.; Telfer, T.C. Use of geographic information systems for aquaculture and recommendations for development of spatial tools. Aquaculture 2020, 12, 664-677. [CrossRef]

20. Radiarta, I.N.; Saitoh, S.; Miyazono, A. GIS-based multi-criteria evaluation models for identifying suitable sites for Japanese scallop (Mizuhopecten yessoensis) aquaculture in Funka Bay, southwestern Hokkaido, Japan. Aquaculture 2008, 284, 127-135. [CrossRef]

21. Longley, P.A.; Goodchild, M.F.; Maguire, D.J.; Rhind, D.W. Geographic Information Science and Systems; John Wiley \& Sons: Hoboken, NJ, USA, 2015.

22. Giap, D.H.; Yi, Y.; Yakupitiyage, A. GIS for land evaluation for shrimp farming in Haiphong of Vietnam. Ocean Coast. Manag. 2005, 48, 51-63. [CrossRef]

23. Landucci, F.S.; Rodrigues, D.F.; Fernandes, A.M.; Scott, P.C.; Poersch, L.H.S. Geographic information system as an instrument to determine suitable areas and identify suitable zones to the development of emerging marine finfish farming in Brazil. Aquac. Res. 2020, 51, 3305-3322. [CrossRef]

24. Mamat, N.; Rasam, A.R.A.; Adnan, N.A.; Abdullah, I.C. GIS-based multi-criteria decision making system for determining potential site of oyster aquaculture in Terengganu. In Proceedings of the IEEE 10th International Colloquium on Signal Processing and Its Applications (CSPA), Kuala Lumpur, Malaysia, 7-9 March 2014; pp. 71-76.

25. Yin, S.; Takeshige, A.; Miyake, Y.; Kimura, S. Selection of suitable coastal aquaculture sites using multi-criteria decision analysis in Menai Strait, UK. Ocean Coast. Manag. 2018, 165, 268-279. [CrossRef]

26. Nayak, A.K.; Kumar, P.; Pant, D.; Mohanty, R.K. Land Suitability modelling for enhancing fishery resource development in Central Himalayas (India) using GIS and multi-criteria evaluation approach. Aquac. Eng. 2018, 83, 120-129. [CrossRef]

27. Esmaeilpour-Poodeh, S.; Ghorbani, R.; Hosseini, S.A.; Salmanmahiny, A.; Rezaei, H.; Kamyab, H. A multi-criteria evaluation method for sturgeon farming site selection in the southern coasts of the Caspian Sea. Aquaculture 2019, 513, 734416. [CrossRef]

28. Beard, K.; Kimble, M.; Yuan, J.; Evans, K.S.; Liu, W.; Brady, D.; Moore, S. A method for heterogeneous spatio-temporal data integration in support of marine aquaculture site selection. J. Mar. Sci. Eng. 2020, 8, 96. [CrossRef]

29. Yunis, C.R.C.; López, R.S.; Cruz, S.M.O.; Castillo, E.B.; López, J.O.S.; Trigoso, D.I.; Briceño, N.B.R. Land suitability for sustainable aquaculture of rainbow trout (Oncorhynchus mykiss) in Molinopampa (Peru) based on RS, GIS, and AHP. ISPRS Int. J. Geo-Inf. 2020, 9, 28. [CrossRef]

30. Ghobadi, M.; Nasri, M.; Ahmadipari, M. Land suitability assessment (LSA) for aquaculture site selection via an integrated GIS-DANP multi-criteria method: A case study of lorestan Province, Iran. Aquaculture 2021, 530, 735776. [CrossRef]

31. Eastman, J.R. Multi-criteria evaluation and GIS. In Geographical Information Systems; Goodchild, M.F., Maguire, D.J., Rhind, D.W., Longley, P.A., Eds.; John Wiley and Sons: New York, NY, USA, 1999; pp. 493-502.

32. Cardia, F.; Ciattaglia, A.; Corner, R. Guidelines and Criteria on Technical and Environmental Aspects of Cage Aquaculture Site Selection in the Kingdom of Saudi Arabia; Food and Agriculture Organization of the United Nations: Rome, Italy, 2017; (English Version).

33. United States Geological Survey-USGS. Earth Explorer. Available online: https:/ / earthexplorer.usgs.gov / (accessed on 19 March 2020).

34. FAO; UNESCO. Soil Map of The World: South East Asia. Soil Map World; FAO: Rome, Italy, 1979; Volume 9. Available online: http: / / www.fao.org/soils-portal/data-hub/soil-maps-and-databases/faounesco-soil-map-of-the-world/en/ (accessed on 15 August 2021).

35. Hossain, M.S.; Chowdhury, S.R.; Das, N.G.; Sharifuzzaman, S.M.; Sultana, A. integration of GIS and multi-criteria decision analysis for urban aquaculture development in Bangladesh. Landsc. Urban Plan. 2009, 90, 119-133. [CrossRef]

36. Saaty, T.L. How to make a decision: The analytic hierarchy process. Eur. J. Oper. Res. 1990, 48, 9-26. [CrossRef]

37. Penang State of Forestry Department. Available online: https://jhn.penang.gov.my/index.php/en/ (accessed on 19 March 2020).

38. Pathansali, D.; Zainol, S. National Plan for Development of Aquaculture in Malaysia. Available online: http://www.fao.org/3/ X5629E/x5629e0h.htm (accessed on 19 March 2020).

39. Chahinez, L.; Abderrahim, H.; El Islem, B.N. Site selection for finfish cage farming using spatial multi-criteria evaluation and their validation at field in the bay of Souahlia (Algeria). Aquac. Int. 2020, 28, 2419-2436. [CrossRef]

40. Perez, O.M.; Telfer, T.C.; Ross, L.G. Geographical information systems-based models for offshore floating marine fish cage aquaculture site selection in Tenerife, Canary Islands. Aquac. Res. 2005, 36, 946-961. [CrossRef]

41. Vafaie, F.; Hadipour, A.; Hadipour, V. GIS-based fuzzy multi-criteria decision making model for coastal aquaculture site selection. Environ. Eng. Manag. J. 2015, 14, 2415-2426. [CrossRef]

42. Mustafa, A.; Asaad, A.I.J.; Rimmer, M.A. Land characteristics and suitability for tilapia culture at different seasons in brackish water ponds of Bontoa Subdistrict, Maros Regency, Indonesia. IOP Conf. Ser. Earth Environ. Sci. 2020, 473, 012072. [CrossRef]

43. Estigade, A.P.; Astuti, A.P.; Wicaksono, A.; Maitela, T.; Widyatmanti, W. Remote Sensing and GIS Application for Water Environment Suitability Evaluation in Lampung and Hurun Bay. IOP Conf. Ser. Earth Environ. Sci. 2009, 256, 012016. [CrossRef]

44. Longdill, P.C.; Healy, T.R.; Black, K.P. An integrated GIS approach for sustainable aquaculture management area site selection. Ocean Coast. Manag. 2008, 51, 612-624. [CrossRef] 